This document is confidential and is proprietary to the American Chemical Society and its authors. Do not copy or disclose without written permission. If you have received this item in error, notify the sender and delete all copies.

\title{
Transfer and Ecotoxicity of Titanium Dioxide Nanoparticles in the Terrestrial and Aquatic Ecosystems: A Microcosm Study
}

\begin{tabular}{|r|l|}
\hline Journal: & Environmental Science \& Technology \\
\hline Manuscript ID & es-2018-02970a.R1 \\
\hline Manuscript Type: & Article \\
\hline Date Submitted by the Author: & n/a \\
\hline Complete List of Authors: & $\begin{array}{l}\text { Vijayaraj, Vinita; CNRS, ECOLAB } \\
\text { Liné, Clarisse; CNRS, ECOLAB } \\
\text { Cadarsi, Stéphanie; CNRS, ECOLAB } \\
\text { Salvagnac, Clément; CNRS, ECOLAB } \\
\text { Baqué, David; CNRS, ECOLAB } \\
\text { Elger, Arnaud; EcoLab } \\
\text { Barret, Maialen; CNRS, ECOLAB } \\
\text { Mouchet, Florence; Université de Toulouse, EcoLab } \\
\text { Larue, Camille; CNRS, ECOLAB }\end{array}$ \\
\hline
\end{tabular}


1 Transfer and Ecotoxicity of Titanium Dioxide Nanoparticles in Terrestrial and Aquatic

3 Vinita Vijayaraj, ${ }^{\dagger}$ Clarisse Liné, ${ }^{\dagger}$ Stéphanie Cadarsi $^{\dagger}{ }^{\dagger}$ Clément Salvagnac, $^{\dagger}$ David Baqué, ${ }^{\dagger}$ 4 Arnaud Elger, ${ }^{\dagger}$ Maialen Barret,${ }^{\dagger}$ Florence Mouchet ${ }^{\dagger}$ and Camille Larue ${ }^{*}, \dagger$

6 'EcoLab, Université de Toulouse, CNRS, Toulouse, France

\section{Graphical abstract}

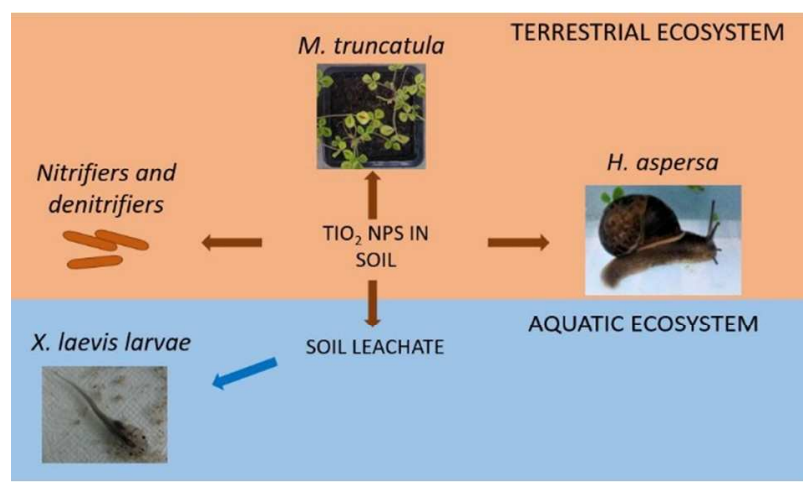

11 
13 ABSTRACT: With the advancement in nanotechnology, particularly the use of $\mathrm{TiO}_{2}$ 14 nanoparticles (NPs), there is a need to study their release into the environment and assess the 15 related risk in an environmentally relevant contamination scenario. In the present study, the 16 transfer and toxicity of $\mathrm{TiO}_{2} \mathrm{NPs}$ in microcosms mimicking a terrestrial and an aquatic 17 ecosystems were evaluated. The contaminated soil was prepared by spiking natural soils and 18 used as the basis for all exposure systems including preparation of soil leachates for amphibian 19 exposure. Results demonstrated significant reductions in bacterial (-45\%) and archaeal (-36\%) 20 nitrifier abundance; significant translocation of Ti to $M$. truncatula leaves $(+422 \%)$; significant 21 reductions in plant height (-17\%), number of leaves (-29\%), and aboveground biomass $(-53 \%)$;

22 non-significant Ti uptake in snail foot and viscera, and excretion in feces; and genotoxicity to $X$.

23 laevis larvae $\left(+119 \%\right.$ micronuclei). Our study highlights a possible risk of engineered $\mathrm{TiO}_{2} \mathrm{NPs}$

24 in the environment in terms of trophic transfer and toxicity in both terrestrial and aquatic 25 environments. 


\section{INTRODUCTION}

27 Nanoparticles (NPs) are particles with at least one dimension smaller than $100 \mathrm{~nm} \cdot \cdot^{1}$ Compared

28 with their micro/macro particle counterparts, NPs have a larger surface area over volume ratio, ${ }^{2}$

29 and number of surface atoms, which results in increased surface energy and reactivity. ${ }^{-}$The

30 understanding of their unique properties has rendered them indispensable in several fields of

31 science and technology. Although not all NPs may be toxic, because they are manufactured in a

32 variety of sizes and shapes for use in a multitude of products and industrial processes, ${ }^{4}$ they

33 could pose different potential hazards. ${ }^{5,6}$ Despite the recommendation by the National Organic

34 Standards Board in 2010, products containing NPs are still being manufactured worldwide. ${ }^{4}$ It is

35 therefore necessary to understand the risks associated with their release in the environment.

36 Among the most widely used NPs are silver and titanium dioxide $\left(\mathrm{TiO}_{2}\right) \mathrm{NPs} \cdot{ }^{7} \mathrm{TiO}_{2} \mathrm{NPs}$ are

37 commonly known for their photocatalytic applications and used as semiconductors, $\stackrel{8}{\text { additives in }}$

38 food, ${ }^{9}$ and in cosmetic products. ${ }^{10}$ Ti is also a widespread element in the environment, with

39 concentrations in soils ranging for instance from $43 \mathrm{mg} \mathrm{kg}^{-1}$ in sand to $1671 \mathrm{mg} \mathrm{kg}^{-1}$ in clayey

40 soil. ${ }^{11}$ The concern, however, is the increase in this background concentration beyond an

41 environmentally safe threshold, in addition to the potential toxicity of these NPs, on their own,

42 due to the differences in their properties and behavior when compared with natural Ti.

43 Ultimately these NPs will reach the environment. ${ }^{12}$ In wastewater treatment plants, NPs partition

44 between treated water and sludge effluents. Through the discharge of treated water, NPs can

45 reach aquatic ecosystems. But the majority $(99 \%)^{13}$ that remains in sewage sludge is dispersed

46 into agricultural fields as fertilizer. ${ }^{14}$ Runoff from these polluted soils can in turn reach water

47 bodies. A recent study by Sun et al. $\frac{15}{}$ predicted the concentrations of $\mathrm{TiO}_{2} \mathrm{NPs}_{\text {in }}$ surface waters

48 to be $\sim 2.17 \mu \mathrm{g} \mathrm{L}^{-1}$, in sludge $1.60 \mathrm{~g} \mathrm{~kg}^{-1}$, and in sludge-treated soils $61.10 \mathrm{mg} \mathrm{kg}^{-1}$. An 
49 accumulation in both terrestrial and aquatic organisms could be carried upward into the food

50 chain by primary and secondary consumption routes.

51 Negative effects have already been noticed, as a result of NP exposure, in terrestrial and aquatic

52 organisms at the single-organism scale, $\stackrel{16}{ }$ but the study of NP effects in a simplified food web is

53 not very common. Suggestions have been made that certain NPs can bioaccumulate and possibly

54 bio-magnify in the trophic chain. $\frac{17,18}{}$ Yeo and Nam ${ }^{19}$ compared the bioaccumulation of $\mathrm{TiO}_{2} \mathrm{NPs}$

55 and carbon nanotubes in a paddy ecosystem, and observed a bioaccumulation from plankton to

56 ricefish. In a microcosm containing soil, lettuce, crickets, and lizards, Servin et al..$^{20}$

57 demonstrated that the availability of $\mathrm{CuO}$ NPs to terrestrial organisms can be modified by

58 weathering. Using leaf litter decomposition as a functional marker for ecotoxicity in freshwater

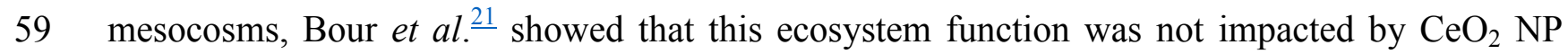

60 exposure, in line with the absence of significant differences in numbers, growth, or development

61 of chironomid larvae. However, studies are lacking in terms of a real-life scenario where transfer

62 of $\mathrm{TiO}_{2}$ NPs occurs from the soil into the water compartment and their impact on, and uptake by,

63 relevant organisms of these environments.

64 In the present study, the aim was to combine two microcosms mimicking both terrestrial (soil, 65 soil microbial communities, alfalfa plants, and snails) and aquatic (soil leachates and amphibian

66 larvae) compartments to (a) determine whether there is a transfer of Ti within and between these

67 two compartments and (b) evaluate the toxicity of $\mathrm{TiO}_{2} \mathrm{NPs}$ to soil microbial communities (total

68 abundance and abundance of functional guilds), plant (height, number of leaves, aboveground

69 biomass, chlorophyll), snail (mortality, avoidance behavior), and amphibian larvae (mortality,

70 growth, and genotoxicity). Our study contributes valuable data in terms of the impact of $\mathrm{TiO}_{2}$ 
71 NPs on environmentally relevant bioindicators of pollution and provides an insight into

72 implications for food safety and ecotoxicological risk assessment.

74 1. MATERIALS AND METHODS

\section{1. $\mathrm{TiO}_{2} \mathrm{NP}$ characterization and suspension preparation}

$76 \mathrm{TiO}_{2}$ NPs used in this study were provided by Sigma-Aldrich (P25); they have been widely used

77 in ecotoxicological studies, permitting easy comparisons. They consist of $80 \%$ anatase and $20 \%$

78 rutile with a nominal diameter of $25.0 \pm 5.7 \mathrm{~nm}$; are polyhedral, uncoated, with a specific surface

79 area of $46 \pm 1 \mathrm{~m}^{2} \mathrm{~g}^{-1}$ and zeta potential in ultrapure water of $-10.5 \pm 2.6 \mathrm{mV}$ (File S1). ${ }^{22}$ The

$80 \mathrm{TiO}_{2} \mathrm{NP}$ suspension was freshly prepared before soil contamination $\left(10000 \mathrm{mg} \mathrm{L}^{-1}\right)$; it was

81 vortexed for $30 \mathrm{~s}$ and agitated while pipetting to keep it homogenized.

82

\section{1.2. Terrestrial exposure}

\subsubsection{Exposure medium preparation}

85 The two main conditions in this study were the control soil and the spiked soil, from which all 86 conditions were derived. Soils were silty sand (Lufa Speyer 2.1; File S2) prepared with 20\%

$87(\mathrm{w} / \mathrm{w})$ commercial compost to sustain proper plant growth (final soil mixture $\mathrm{pH}$ : 5.3, organic

88 matter content: $12.6 \%$ ). For the spiked soil, $500 \mathrm{mg} \mathrm{kg}^{-1}$ of $\mathrm{TiO}_{2} \mathrm{NPs}$ were added to mimic

89 several years of sewage sludge spreading on agricultural soils. $\frac{15}{3}$ Both control and spiked soils

90 were mixed with either Millipore water or with NP suspension at a ratio of 1:1 (w:w). After

91 shaking at $100 \mathrm{rpm}$ for $2 \mathrm{~h}$, soils were filtered to eliminate excess water, dried, and transferred to 
92 small plastic pots, $7 \times 7 \times 6.4 \mathrm{~cm}$ (Soparco, France). This mixing procedure was chosen to

93 ensure a homogenous contamination of the soil matrix.

94

\subsubsection{Medicago truncatula exposure to $\mathrm{TiO}_{2} \mathrm{NPs}$}

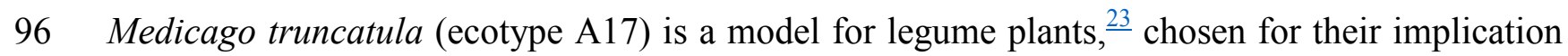

97 in the nitrogen cycle. $\frac{24}{}$ Seeds were kindly provided by Dr. Manuel Gonzalez-Guerrero,

98 Universidad Politécnica de Madrid, Spain. They were first scarified and soaked overnight in

99 water, in the dark. They were then placed in Petri dishes (6 to 7 seeds/Petri dish) with Hoagland

100 agar medium for germination at $4^{\circ} \mathrm{C}$ for $72 \mathrm{~h}$, before transferring to the soil pots. Seedlings $(n=$

10110 per condition) were biomonitored every day for the number of leaves, height, and chlorophyll

102 levels using a SPAD-meter (SPAD-502 chlorophyll meter, Minolta Camera Co., Japan). After 60

103 days, plants were harvested. Dry weights were recorded after $48 \mathrm{~h}$ at $60^{\circ} \mathrm{C}$ prior to $\mathrm{Ti}$

104 quantification in leaves.

105

\subsubsection{Impact of $\mathrm{TiO}_{2}$ NPs on soil microbial communities}

107 The microbiological analysis focused on soil nitrifiers and denitrifiers to further investigate NP

108 impact on the nitrogen cycle. Upon plant harvest, three cores of whole-depth bulk soil, deprived

109 of roots (and without further processing), were collected at $3 \mathrm{~cm}$ from the stem axis from

110 individual soil pots ( $\mathrm{n}=6$ per condition). The three cores were homogenized, and $300 \mathrm{mg}$

111 composite subsamples were stored at $-20^{\circ} \mathrm{C}$ until DNA isolation. The FastDNA SPIN Kit for

112 Soil was used according to the manufacturer's instructions (MP Biomedicals laboratories, Unites

113 States). The quality and quantity of DNA extracts were determined using a NanoDrop

114 spectrophotometer. Quantitative PCR (qPCR) was used to measure the abundance of total soil 
115 bacteria targeting the universal $16 \mathrm{~S}$ rRNA gene as well as archaeal ammonia monooxygenase A 116 genes $(a m o A)$ for ammonia oxidizing archaea (AOA, nitrifiers), bacterial amoA for ammonia 117 oxidizing bacteria (AOB, nitrifiers), and the bacterial nitrite reductase (nirK and $\operatorname{nirS}$ ) and the

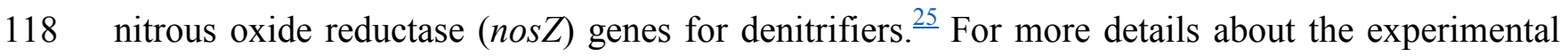
119 procedure, see File S3.

122 Snails were chosen for this experiment as sensitive bioindicators of pollution in the 123 environment. ${ }^{26}$ They were obtained from a snail breeding farm to ensure homogeneity. After a 48

$124 \mathrm{~h}$ depuration step, they were transferred to clean boxes containing $5 \mathrm{~g}$ of dry soil (after plant 125 harvest) mixed with $3 \mathrm{~mL}$ of Millipore water ( $n=6$ per condition). Soil moisture was set high 126 (189\% of the water holding capacity), to sustain high hygrometry in microcosms and thus snail 127 activity. The experimental model included only soil exposure, which was renewed each day for 12810 days; snail feces were collected daily. After removal, soils were dried and weighted to 129 determine the quantity consumed by each snail over $24 \mathrm{~h}$. Following $72 \mathrm{~h}$ of depuration, snails 130 were rinsed and stored at $-20^{\circ} \mathrm{C}$. Snail foot and viscera were separated and dried prior to $\mathrm{Ti}$ 131 quantification. $^{26}$

\subsection{Aquatic exposure}

\subsubsection{Exposure media for amphibian larvae}

135 Exposure media for amphibian larvae were prepared using a new batch of control and spiked 136 soils. Soils (1 kg of dry matter) were mixed with 10 volumes (ratio 1:10) of mineral water 137 (Volvic ${ }^{\circledR}$; Ti under detection limit of inductively coupled plasma-optical emission spectroscopy 
138 [ICP-OES]) according to the adapted static leaching procedure of the French norm XP 31-210

139 (AFNOR, 1992) without filtration..$^{29}$ After $24 \mathrm{~h}$ of stirring, the mixtures were allowed to settle for

$1402 \mathrm{~h}$, and the supernatant suspensions were collected by siphoning into glass flasks. Ten different

141 exposure conditions were set up (Table 1).

142

143 Table 1: Amphibian larvae exposure conditions (CS : control soil, SS : spiked soil)

\begin{tabular}{|c|c|}
\hline Condition & Preparation \\
\hline $\mathrm{NC}$ & Pure Volvic $\AA$ water \\
\hline $\mathrm{PC}$ & $40 \mathrm{mg} \mathrm{L}^{-1}$ cyclophosphamide in Volvic ${ }^{\circledR}$ water \\
\hline ICP equiv of $\mathrm{CS}$ & $3.6 \mathrm{mg} \mathrm{L}^{-1} \mathrm{TiO}_{2}$ NPs in Volvic $\AA$ water \\
\hline CS Raw & Raw leachates from control soil \\
\hline CS50 & $50 \%$ raw leachates from control soil $+50 \%$ Volvic $\AA$ water \\
\hline $\mathrm{CS} 25$ & $25 \%$ raw leachates from control soil $+75 \%$ Volvic $\AA$ water \\
\hline $\mathrm{ICP}$ equiv $\mathrm{SS}$ & $12.3 \mathrm{mg} \mathrm{L}^{-1} \mathrm{TiO}_{2} \mathrm{NPs}$ in Volvic $\AA$ water \\
\hline SS Raw & Raw leachates from spiked soil \\
\hline SS50 & $50 \%$ raw leachates from spiked soil $+50 \%$ Volvic $\AA$ water \\
\hline $\mathrm{SS} 25$ & $25 \%$ raw leachates from spiked soil $+75 \%$ Volvic $\AA$ water \\
\hline \multicolumn{2}{|c|}{$\begin{array}{l}\mathrm{NC}=\text { negative control; } \mathrm{PC}=\text { positive control (genotoxicity assay); ICP equiv of } \mathrm{CS}=\text { equivalent } \\
\text { Ti concentration of } \mathrm{CS} \text { in Volvic } \AA \text {; ICP equiv } \mathrm{SS}=\mathrm{ICP} \text { equivalent Ti concentration of } \mathrm{SS} \text { in } \\
\text { Volvic } \AA \text {. }\end{array}$} \\
\hline
\end{tabular}


$146 X$. laevis, a widely used model in ecotoxicology,,$\underline{27, \underline{28}}$ are filter-feeders, and can be contaminated

147 via skin contact, water filtration via gills, and breeding exposure. X. laevis larvae (stage 50 of the

148 development table of Nieuwkoop \& Faber $^{30}$ ) were exposed in semi-static conditions based on

149 modified ISO $21427-1 . \underline{31}$ The larvae $(n=15$ per condition) were taken from the same hatch to

150 reduce inter-animal variability. They were submitted to daily renewal of media and fed with fish

151 food TetraPhyll®. After 12 days of exposure, mortality was recorded and larvae anaesthetized

152 (MS222, Sandoz, France) to take pictures and evaluate growth inhibition (Image J). Genotoxicity

153 was assessed through the micronucleus test $\stackrel{31}{ }$ : blood was extracted from the heart of each

154 anesthetized larva, and micronucleated erythrocytes per thousand cells (ME\%o) were counted

155 under optical microscope following hematoxylin-eosin staining.

157 1.4. Ti uptake: acid digestion and ICP-OES

158 Acid digestion was done in a DigiPrep ${ }^{\circledR}$ heating system, using $\mathrm{HNO}_{3}, \mathrm{NH}_{4} \mathrm{~F}$, and $\mathrm{HClO}_{4}$ as well 159 as $\mathrm{H}_{2} \mathrm{O}_{2}$, with a temperature of $100^{\circ} \mathrm{C}$ and several evaporation steps. ${ }^{11}$ Digested samples were 160 diluted in $5 \% \mathrm{HNO}_{3}$. For soil, a filtration step was necessary $(0.45 \mu \mathrm{m}$ syringe filters). The 161 samples were then analyzed by ICP-OES with control samples (blanks with only chemicals and 162 standard reference material NIST 1573a: tomato leaves) (IRIS Intrepid II XDL, Thermo 163 Scientific, United States). Ti recovery from $\mathrm{TiO}_{2}$ NPs has been calculated to be $88.2 \pm 2.1 \% .^{\underline{11}}$

166 Data were checked for homoscedacity and normality. When assumptions were met for 167 parametric analyses, a Welsh $t$-test or a one way ANOVA were used. Otherwise, a Wilcoxon test 
168 or a Kruskal-Wallis test followed by a Dunn's post hoc test were applied. A principal component 169 analysis (PCA) was carried out on plant elemental content to investigate $\mathrm{TiO}_{2} \mathrm{NP}$ impact on plant 170 nutrition. All statistical analyses were performed using the $\mathrm{R}$ statistical software (version

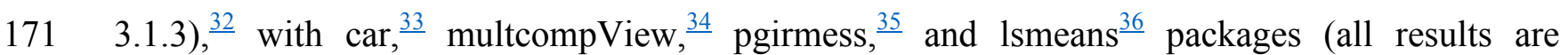
172 gathered in Table S4). Data is displayed as median \pm interquartile range, average is shown by a 173 red dot.

\section{RESULTS AND DISCUSSION}

\subsection{Terrestrial ecosystem}

\subsubsection{Ti concentration in soil}

178 As expected, the addition of $\mathrm{TiO}_{2}$ NPs lead to a significant increase in Ti concentration in spiked 179 soil in comparison with the control soil $(p=0.01)$. The average concentration in the control soil 180 was $278.0 \pm 13.4 \mathrm{mg} \mathrm{kg}^{-1}$, while that in spiked soil was $341.7 \pm 12.2 \mathrm{mg} \mathrm{kg}^{-1}$ (see File S5A).

181 Although the soils were spiked with $500 \mathrm{mg} \mathrm{kg}^{-1} \mathrm{TiO}_{2} \mathrm{NPs}$ (300 mg Ti kg-1 equivalent), the 182 average increased concentration of Ti in spiked soils after leaching was below $300 \mathrm{mg} \mathrm{kg}^{-1} \mathrm{Ti}$.

183 Considering that the soil used in this study was $88 \%$ sandy, this could be explained as a loss of $184 \mathrm{Ti}$ into the water compartment during the leaching procedure, as suggested by our previous 185 results. $\frac{11}{}$

188 After 60 days of exposure, plants grown in the spiked soil were significantly smaller than those 189 grown in the control soil $(p<0.001)$ with average heights of $4.3 \pm 0.3 \mathrm{~cm}$ and $6.2 \pm 0.3 \mathrm{~cm}$, 
190 respectively (Figure 1A). Plant heights were similar until day 12, after which exposed plants had 191 a 17\% smaller size (File S5B). Along the development, non-exposed plants produced 192 significantly more leaves $(p=0.01)$ with $c a$. seven against five leaves for exposed plants (Figure 193 1B). A significant reduction in aboveground biomass (-53\%) was also observed for exposed 194 compared to non-exposed plants $(p<0.001$; File S5C). Chlorophyll levels tended to be lower in 195 the spiked conditions than in the control conditions, but no significant difference was detected 196 (File S5D). In terms of Ti uptake, concentration in the exposed leaves was significantly higher 197 compared to the non-exposed leaves $(p<0.01)$ with respective concentrations of $196.6 \pm 53.1$

$198 \mathrm{mg} \mathrm{kg}^{-1}$ and $37.6 \pm 7.9 \mathrm{mg} \mathrm{kg}^{-1}$ (Figure 1C). Exposure to $\mathrm{TiO}_{2} \mathrm{NPs}$ tended to impact plant 199 ionome: exposed plants were significantly enriched in zinc, lead, sodium, manganese, 200 phosphorus but contained less copper, iron, potassium, sulfur, molybdenum, and boron (Figure 201 1D). 
210 The significant differences between non-exposed and exposed plants indicate an impact of $\mathrm{TiO}_{2}$

211 NPs tending to inhibit plant growth and shoot biomass. Rafique et al..$^{37}$ showed that $\mathrm{TiO}_{2} \mathrm{NP}$

212 concentrations of 20 to $60 \mathrm{mg} \mathrm{kg}^{-1}$ (sandy loam) led to a dose-related increase in root and shoot

213 length and biomass in wheat plants exposed for 60 days. However, they demonstrated that

214 concentrations of 80 to $100 \mathrm{mg} \mathrm{kg}^{-1}$ gradually inhibited root and shoot length and reduced plant

215 biomass. In our study, Ti concentrations were fivefold higher in the plants exposed (341.7 $\mathrm{mg} \mathrm{kg}^{-}$

$21{ }^{1}{ }^{1}$ ) for 60 days when compared with the non-exposed plants. Our results also conform to those

217 obtained in a recent study by Larue et al., which showed that wheat plants exposed for 3 weeks

218 to sandy soils spiked with $500 \mathrm{mg} \mathrm{kg}^{-1}$ of $\mathrm{TiO}_{2} \mathrm{NPs}$ took up significantly more Ti than the

219 control. ${ }^{11}$ In addition, plants initially developing at the same rate began to show a consistent

220 change in growth rate by the beginning of the third week of exposure. We hypothesize that one

221 reason for the significant difference in plant development is the impact of $\mathrm{TiO}_{2} \mathrm{NPs}$ on plant

222 ionome. Among the deficient elements in plants grown in $\mathrm{TiO}_{2} \mathrm{NP}$-spiked soils is potassium,

223 which is essential for plant growth, development, regulation, and crop yield. ${ }^{38}$ Maathuis ${ }^{39}$ posited

224 that at low potassium levels, sodium can replace potassium due to its structural similarity, which

225 is evidenced in our study, where the plants deficient in potassium are enriched, instead, in

226 sodium. Pi et al. ${ }^{40}$ showed that when plants were exposed to stress ( $\mathrm{K}$ deficient environment),

227 they replaced $\mathrm{K}^{+}$with $\mathrm{Na}^{+}$, but did not recover to the same extent as the control group, which

228 could explain why the exposed plants were significantly smaller and less productive-with a

229 deficiency in potassium - than the non-exposed plants. However, contrary to our results, Servin

230 et al. ${ }^{41}$ demonstrated an increase in potassium in cucumber plants exposed to $\mathrm{TiO}_{2} \mathrm{NPs}$. This

231 difference might be attributed to the plant models used. Also in line with our results, Rafique et

$232 a l .^{42}$ showed an increase in phosphorus availability in wheat plants exposed to $\mathrm{TiO}_{2} \mathrm{NPs}$. In 
233 addition, ICP analysis showed that spiked soil plants were deficient in other micronutrients, such 234 as boron, copper, iron, and molybdenum, which are necessary for the plant physiological 235 processes $^{\frac{43}{3}}$ and, therefore, could be explanative of the significant reduced development of the 236 exposed plants.

\subsubsection{Impact of $\mathrm{TiO}_{2}$ NPs on soil microbial communities}

239 There was no difference between the abundance of the total bacteria (16S rRNA) in the control 240 and spiked soils $(p=0.74)$, with the average number of gene copies per gram of soil being $1.92 \times$

$24110^{10} \pm 1.95 \times 10^{9}$ and $1.83 \times 10^{10} \pm 1.97 \times 10^{9}$, respectively (Figure 2).

242 Evaluation of amoA genes, both for $\mathrm{AOA}$ and $\mathrm{AOB}$, indicated a significant decrease in

243 abundance in the spiked soil ( $p=0.007$ and $p=0.001$, respectively). The average number of 244 gene copies/g soil was $2.97 \times 10^{7} \pm 2.48 \times 10^{6}$ for non-exposed AOA and $2.07 \times 10^{7} \pm 1.31 \times 10^{6}$

245 for exposed AOA, while those for non-exposed AOB and exposed AOB were $1.90 \times 10^{7} \pm 1.04$

$246 \times 10^{6}$ and $1.05 \times 10^{7} \pm 1.11 \times 10^{6}$, respectively (Figure 2).

247 In the case of the denitrifying genes nirK, nirS, and nos $Z$, no significant difference was found 248 between the control and spiked soils ( $p=0.49, p=0.76$, and $p=0.67$, respectively). The average 249 number of gene copies/g soil obtained for nirK, nirS, and nos Z were $3.81 \times 10^{8} \pm 3.47 \times 10^{7}, 2.00$ $250 \times 10^{7} \pm 1.80 \times 10^{6}$, and $1.91 \times 10^{9} \pm 1.52 \times 10^{8}$, respectively (Figure 2) 


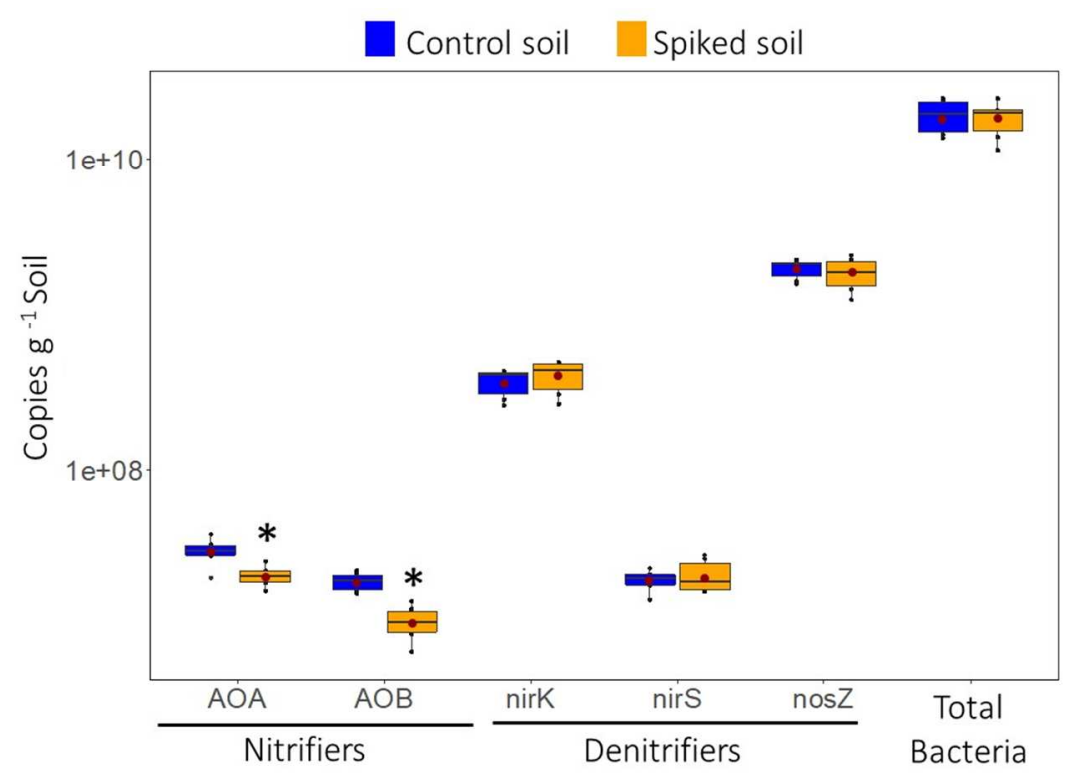

253

271 AOA abundance at $\mathrm{TiO}_{2} \mathrm{NP}$ concentrations from 0.05 to $500 \mathrm{mg} \mathrm{kg}^{-1}$. The magnitude of AOA 272 decrease in our experiment was $35.9 \pm 4.5 \%$, which is in agreement. In the case of AOB,

Figure 2: Impact on bacterial nitrifier and denitrifier genes. Nitrifier genes include the ammonia oxidizing archaea (AOA) and the ammonia oxidizing bacteria (AOB) ammonia monooxygenase A gene ( $(\mathrm{mo} \mathrm{A})$ ). The denitrifier genes include the bacterial nitrite reductase genes (nirK and $\mathrm{nirS}$ ) and the bacterial nitrous oxide reductase gene (nosZ) for denitrification. Values on the y axis are expressed on the logarithm scale. Asterisks represent significant differences $(p<0.05)$. Average Ti concentrations in spiked soil $=341.7 \pm 12.2 \mathrm{mg} \mathrm{kg}^{-1}$; average Ti concentrations in control soil $=278.0 \pm 13.4 \mathrm{mg} \mathrm{kg}^{-1}$. Exposure: 60 days; $n=6$.

The literature concerning the impact of $\mathrm{TiO}_{2} \mathrm{NPs}$ on the soil microbial communities is scarce. Ge et al..$^{44.45}$ and Simonin et al. ${ }^{46}$ showed reductions in bacterial biomass and shifts in the community structure at high to very high $\mathrm{TiO}_{2} \mathrm{NP}$ concentrations (up to $20 \mathrm{~g} \mathrm{~kg}^{-1}$ ). In our experiment, the total bacterial abundance was not affected probably because the $\mathrm{TiO}_{2} \mathrm{NP}$ concentration was lower. However, the relative abundance of some taxa decreased (soil nitrifiers vs. denitrifiers), suggesting potential consequences on bacterial community functionalities. Interestingly, Simonin et al. evidenced a lack of the classical dose-response relationship. ${ }^{46}$ This phenomenon was explained by the concentration-dependent modifications of NP properties involved in their bioavailability and ecotoxicity. ${ }^{25}$ Simonin et al. ${ }^{46}$ showed a $40 \%$ reduction in 
273 Simonin et $a l . \underline{46}$ evidenced an unusual "U" shape for dose response, with intermediate 274 concentrations of $\mathrm{TiO}_{2}$ NPs significantly decreasing the AOB abundance, and the lowest and 275 highest concentrations showing no significant decrease. Based on the model derived from their 276 experimental data $\left(y=0.009 \times \ln \left(\left[\mathrm{TiO}_{2}\right]\right)^{2}-0.0215 \times \ln \left(\left[\mathrm{TiO}_{2}\right]\right)-0.26\right)$, the estimation of AOB 277 decrease at $341 \mathrm{mg} \mathrm{kg}^{-1}$ would be $6.5 \%$. In our study, we measured a higher decrease: $44.9 \% \pm$ $2787.3 \%$. While Simonin et al. $\frac{46}{}$ attributed the unusual dose-response relationships to the 279 modification of $\mathrm{TiO}_{2} \mathrm{NP}$ properties based on their concentrations (e.g., aggregation of $\mathrm{TiO}_{2} \mathrm{NPs}$ 280 at intermediate and higher concentrations), the discrepancy between results for AOB obtained in 281 their study and ours might be explained by the difference between soil types and thereby 282 between soil-NP interactions. Simonin et al. $\stackrel{46}{ }$ used silty clay, whereas our study used silty sand, 283 highlighting the importance to consider soil type when studying NP fate in the environment.

284 Bissett et al..$^{47}$ discussed the relative insensitivity of denitrifiers to environmental toxicants, and 285 attributed the resistance of this functional guild to their high functional redundancy, niche 286 breadth, and adaptive ability compared with the soil nitrifiers, which have limited phylogenic 287 diversity. In terms of relationship between plants and soil bacteria, we hypothesize that another 288 reason for the inhibition in plant development, and the delay of this impact until the third week, 289 could be an indirect effect of $\mathrm{TiO}_{2}$ NPs on the soil nitrifier community. Indeed, Van Der 290 Heijden ${ }^{48}$ discussed how soil bacteria indirectly affect plant productivity by altering nutrition and 291 resource availability.

\subsubsection{Toxicity and uptake of Ti by $H$. aspersa}

294 No difference in snail mortality was detected along the exposure period. The analysis of total soil 295 consumption by snails from day 1 to day 10 did not reveal any significant difference between 
296 treatments $(p=0.56)$ : the average daily soil consumed by snails amounting to $1.36 \pm 0.17 \mathrm{~g}$ for 297 spiked soil and to $1.23 \pm 0.01 \mathrm{~g}$ for control soil (data not shown). Ti concentration in snail foot, 298 viscera, and feces did not show significant difference ( $p=0.78,0.49,0.88$, respectively). Ti 299 uptake in the non-exposed snail foot was $0.33 \pm 0.03 \mathrm{mg} \mathrm{kg}^{-1}$ and in the exposed snail foot was $300 \quad 0.86 \pm 0.30 \mathrm{mg} \mathrm{kg}^{-1}$ (Figure 3A), while for the viscera, the average Ti concentrations after 301 depuration were $0.39 \pm 0.12 \mathrm{mg} \mathrm{kg}^{-1}$ and $0.28 \pm 0.08 \mathrm{mg} \mathrm{kg}^{-1}$ for non-exposed and exposed 302 snails, respectively (Figure 3A). Average Ti concentrations in feces were $367.78 \pm 52.41 \mathrm{mg} \mathrm{kg}^{-1}$ 303 for non-exposed snails and $377.51 \pm 38.88 \mathrm{mg} \mathrm{kg}^{-1}$ for exposed snails (Figure 3B).

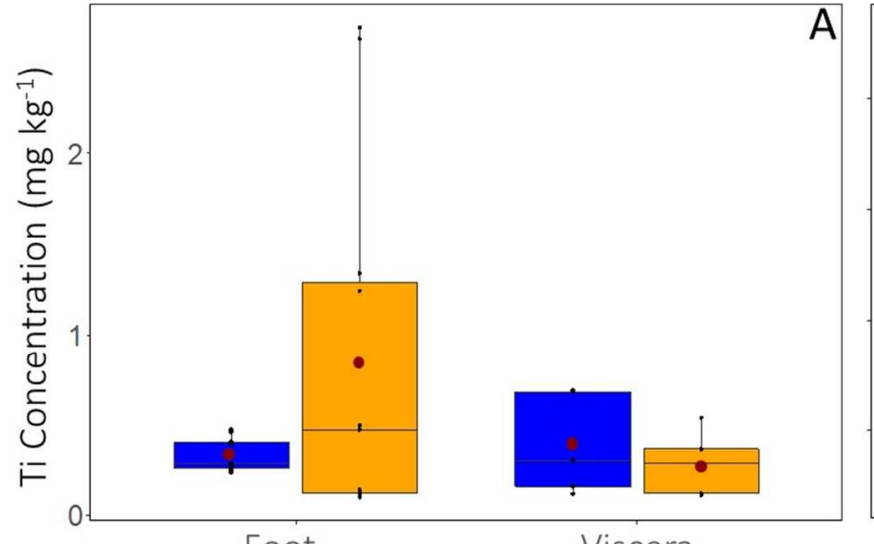

Foot
Viscera

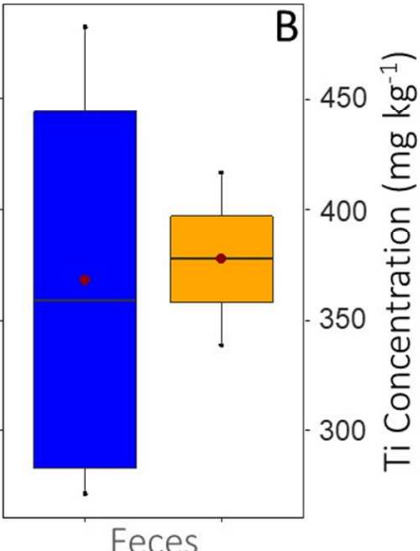

Feces
306

307

308

309

310

311 The total soil consumed by snails in the two treatments was not significantly different, which

312 highlights that there was no behavior of avoidance of the contaminated soil. There was also no

313 significant difference in sequestration of $\mathrm{Ti}$ from soil into snail foot and viscera, or in the 314 excretion in feces. Concentrations in the snail feces show that Ti was quickly eliminated from the 315 snail body via feces. The higher concentrations of Ti in the feces of both the control and spiked 
316 conditions compared to the soil concentrations is presumably due to the digestion of soil organic

317 matter, and thus to a concentration of its mineral fraction. While results on the effects on land

318 snails are in lack, Yeo and $\mathrm{Nam}^{19}$ performed a paddy microcosm study, in which $\mathrm{TiO}_{2} \mathrm{NPs}$ were

319 found to transfer from prey to consumer (biofilm/water dropwort to nematodes/snail) within a

320 period of 17 days, highlighting the potential for bioaccumulation in the food chain. In 2006,

321 Scheifler et al. ${ }^{49}$ evaluated the transfer of several heavy metals in a soil-plant-invertebrate

322 microcosm, using lettuce as primary producer and the snail H. aspersa as primary consumer.

323 They demonstrated that while copper and nickel were not accumulated in the snail body, there

324 was a gradual increase in cadmium and zinc, and a rapid accumulation of lead in snails, but more

325 than $80 \%$ of this accumulation was contributed from soil exposure rather than plant exposure.

326 Similarly, other studies have demonstrated significant increases in concentrations of metals such

327 as chromium and platinum from contaminated food in $H$. aspersa after 56 days $\underline{\underline{50}}$. Although our

328 results did not show any significant uptake in snail, there was a trend for higher $\mathrm{Ti}$

329 concentrations in snail foot under NP exposure, $c a$. two-fold higher on average than in controls.

330 The absence of a significant effect may be due to the high variability in the concentrations

331 measured, reducing statistical power. Including more replicates and a longer exposure period 332 may be needed to reach a conclusion.

\section{2.2. Aquatic ecosystem}

\subsubsection{Ti in amphibian exposure medium}

336 Titanium in the amphibian exposure media showed a higher concentration of $12.3 \pm 0.15 \mathrm{mg} \mathrm{L}^{-1}$

337 in the raw spiked soil leachates compared to $3.6 \pm 0.18 \mathrm{mg} \mathrm{L}^{-1}$ in the raw control soil leachates $(p$ 
$338=0.01)$. Whereas the ratio of $\mathrm{Ti}$ found in control soil versus spiked soil was $1: 1.3$, the ratio of $\mathrm{Ti}$

339 found in control soil leachates versus spiked soil leachates was 1:3.4.

340 In the present study, a real environmental exposure model in the aquatic system was designed, 341 taking into account an approximation of expected percentage of $\mathrm{TiO}_{2} \mathrm{NP}$ concentrations coming 342 from the leaching of an agricultural soil into surface waters. Leachate Ti concentrations were 343 much higher than the predicted concentrations of $2.17 \mu \mathrm{g} \mathrm{L}^{-1} \mathrm{TiO}_{2} \mathrm{NPs}$ in surface waters by Sun 344 et al. (2016), which is attributed to the high concentration of soil spiking in our study. The 345 increased ratios of Ti in the spiked soil leachates compared with the control soil leachates mean 346 that more Ti from the spiked soil moved into the water compartment during the preparation of 347 soil leachates than from the control soil. Gogos et al. $\frac{51}{3}$ showed a significantly lower transfer of 348 Ti from contaminated soil to soil leachate $(0.001 \%$ vs. $26 \%$ in our study) but with a different 349 leaching procedure (filtration of the NP suspension through the soil layer vs. run-off simulation 350 over a soil including soil particles with no filtering step).

353 There was no significant mortality $(<20 \%)$ among amphibian larvae exposed to $\mathrm{TiO}_{2} \mathrm{NPs}$. A 354 comparison of the larval lengths after 12 days of exposure showed a significant difference among 355 groups $(p<0.0001)$ (Figure 4A). There was no significant decrease in the length of the larvae 356 exposed to the ICP equivalents of both the spiked and control soil leachates compared to the 357 negative control larvae $(4.77 \pm 0.09 \mathrm{~cm}$ and $4.77 \pm 0.14 \mathrm{~cm}$, respectively, $v s .4 .46 \pm 0.09 \mathrm{~cm})$. 358 Larvae exposed to raw spiked and control soil leachates $(3.31 \pm 0.14 \mathrm{~cm}$ and $3.17 \pm 0.17 \mathrm{~cm}$, 359 respectively) and 50\% diluted spiked and control leachates $(3.21 \pm 0.14 \mathrm{~cm}$ and $3.30 \pm 0.13 \mathrm{~cm}$, 
360 respectively) showed significant lower size compared to the negative control larvae and to the

361 both ICP equivalents. Larvae exposed to $25 \%$ diluted spiked and control soil leachates also

362 showed a significantly reduced size $(3.54 \pm 0.14 \mathrm{~cm}$ and $3.70 \pm 0.11 \mathrm{~cm}$, respectively) compared

363 to both the ICP equivalents, but no significant lower length compared to the negative control

364 larvae. In addition, the larval size tended to increase with the leachate dilution. There was a

365 significant genotoxicity ( $p<0.0001$ among groups) in larvae exposed to the ICP equivalent of

366 the spiked soil leachate $(6.60 \pm 0.97$ micronuclei $)$, to the spiked and control soil raw leachates

367 (13.15 \pm 1.81 and $6.08 \pm 0.49$ micronuclei, respectively), and to the $50 \%$ diluted spiked soil

368 leachate $(6.07 \pm 0.90$ micronuclei), compared to the negative control larvae $(1.07 \pm 0.30$

369 micronucleus) (Figure 4B). There was no significant genotoxicity in larvae exposed to the ICP

370 equivalent of the control soil leachate $(4.73 \pm 1.09$ micronuclei), to the $50 \%$ diluted control soil

371 leachate $(3.42 \pm 0.82$ micronuclei), and to the $25 \%$ diluted spiked and control soil leachates (2.57

$372 \pm 1.11$ and $3.50 \pm 0.81$ micronuclei, respectively) compared to the negative control larvae. 


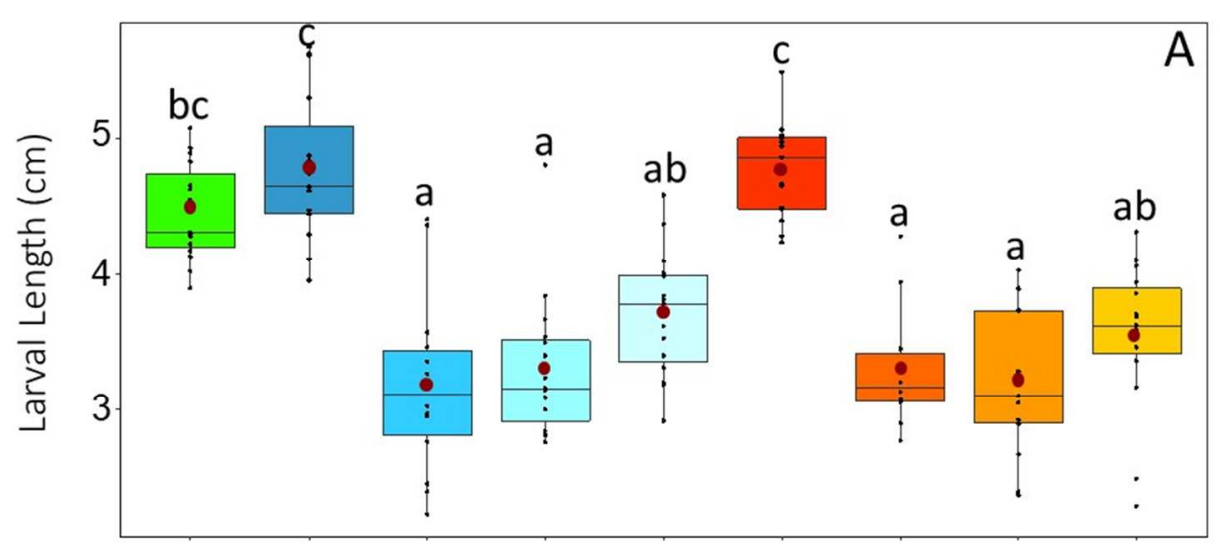

NC ICPCS CSRaw CS50 CS25 ICPSS SSRaw SS50 SS25

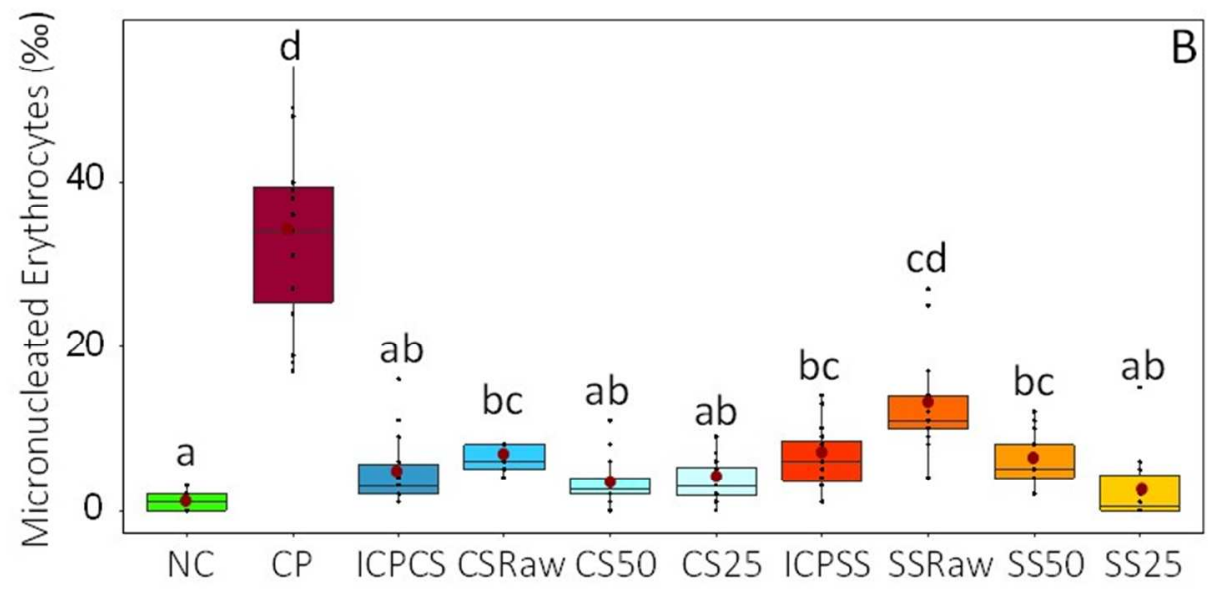

373

374

375

376

377

378

379

380

381

382

383

384

385

386

387

388

Figure 4: A: Impact of $\mathrm{Ti}$ on amphibian ( $X$. laevis) larval length; $\mathrm{B}$ : Percentage of micronucleated erythrocytes (ME\%). Average Ti concentration in the control soil leachates was $3.6 \mathrm{mg} \mathrm{L}^{-1}$ and that in the spiked soil leachates was $12.6 \mathrm{mg} \mathrm{L}^{-1}$. Exposure: 12 days; $n=15$. $\mathrm{NC}=$ negative control; PC = positive control; ICP CS = ICP equivalent of control soil leachates (3.6

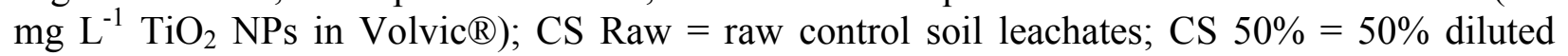

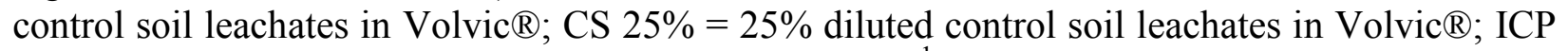
$\mathrm{SS}=\mathrm{ICP}$ equivalent of spiked soil leachates (12.6 mg L $\mathrm{L}^{-1} \mathrm{TiO}_{2} \mathrm{NPs}$ in Volvic $\left.{ }^{\circledR}\right)$; SS Raw $=$ raw spiked soil leachates; SS50\% =50\% diluted spiked soil leachates in Volvic $\AA$; SS 25\% $=25 \%$ diluted spiked soil leachates in Volvic $\AA$ water. Alphabets represent statistically different groups $\underline{(p<0.05) \text {. }}$

Our results demonstrated the inhibition potential of soil leachates on larval growth, and a genotoxicity of both soil leachates and $\mathrm{TiO}_{2} \mathrm{NPs}$. Mouchet et al. $\frac{29}{}$ already demonstrated a toxicity of leachates from contaminated soil to amphibian larvae. Although Chenon et al. $\underline{52}$ showed that sludge-amended soil leachates, including non-lethal dilutions, lead to a decrease in size of amphibian larvae, in our study, the impact of raw control soil leachates was an 
unexpected finding. Therefore, we performed an ICP-OES analysis separately on the compost for

390 elemental concentrations. The results showed an average lead concentration of $9.8 \mathrm{mg} \mathrm{kg}^{-1}$,

391 which might have resulted in a cocktail effect with $\mathrm{TiO}_{2} \mathrm{NPs}$, as Mouchet et al. $\frac{53}{\text { found lead }}$

392 concentrations from $1 \mathrm{mg} \mathrm{L}^{-1}$ to be genotoxic to amphibian larvae. In addition, according to

393 Bekaert et al., $\underline{54}$ pollutants adsorbed onto soil particles may be biologically active when

394 compared with those on filtrates, and as a result, in our study, the presence of soil particles may

395 have contributed to the impact on amphibian growth. The genotoxic potential of $\mathrm{TiO}_{2} \mathrm{NPs}_{\mathrm{s}}$ was

396 evidenced by the increase in the number of micronucleated erythrocytes in larvae exposed to the

397 ICP equivalent of/and the raw spiked soil leachates. Bacchetta et al. $\stackrel{55}{ }$ also demonstrated the

398 toxicity of $\mathrm{TiO}_{2}$ NPs in X. laevis when exposed for $96 \mathrm{~h}$ to concentrations ranging from 10 to 500

$399 \mathrm{mg} \mathrm{L}^{-1}$, resulting in deformities in embryo development. Previous studies have already shown the

400 negative effects of $\mathrm{TiO}_{2}$ NPs on aquatic organisms such as $X$. laevis $\underline{56}$ and Danio rerio, $\underline{57}$ causing

401 deformities and death, while Federici et al. $\frac{58}{}$ showed that $\mathrm{TiO}_{2}$ NPs had toxic effects in rainbow

402 trout at concentrations $<1.0 \mathrm{mg} \mathrm{L}^{-1}$, which could indicate a difference in sensitivities among

403 species. The ICP equivalents of both the raw control soil and raw spiked soil leachates had half

404 or less than half the micronucleated erythrocytes compared with both the raw leachates,

405 respectively, which, again, could be due to a cocktail effect resulting from the presence of lead in

406 the compost.

407 Our study highlights the potential risks of $\mathrm{TiO}_{2}$ NPs in the envionment, showing an upward

408 transfer of $\mathrm{Ti}$ in the terrestrial ecosystem, from soil to plants, and a downward transfer of Ti from

409 soil to the amphibian exposure medium. The inhibition of nitrifiers due to the presence of $\mathrm{TiO}_{2}$

410 NPs can have far-reaching consequences, especially for soil fertility, global ecosystem

411 functions/services, and crop production. The indirect effect of nitrifiers on crop production, and 
412 the uptake of Ti by alfalfa plants, lead to the question of food security. Although we did not find

413 significant uptake of Ti by snails, the concentration-dependent sequestration of Ti in snail foot

414 deserves some attention with the possibility for transfer up the food chain and bioaccumulation

415 over the years. Finally, runoff from contaminated soils ends up in freshwater ecosystems and can

416 be genotoxic to amphibian larvae. By focusing on several experimental models rather than a

417 single-species study, we provide data concerning the distribution of $\mathrm{TiO}_{2} \mathrm{NPs}_{\text {between the }}$

418 terrestrial and aquatic ecosystems, the levels of the terrestrial ecosystem that are most affected-

419 soil bacteria and primary producers - and the risk of toxicity in aquatic ecosystems by leaching

420 of Ti from soil. Three-fourths of our experimental models have been affected by $\mathrm{TiO}_{2} \mathrm{NPs}_{\text {, }}$

421 which is sufficient to acknowledge that precautionary standards for $\mathrm{TiO}_{2} \mathrm{NPs}$ are required. These

422 ecotoxicological effects can be used in future studies to identify safe threshold values of $\mathrm{TiO}_{2}$

423 NPs in the environment and suitable waste disposal methods to ensure that NPs do not reach

424 such high concentrations as identified to be toxic in our study.

\section{ACKNOWLEDGMENT}

427 The authors thank Catherine and Marc Mage, from "L'Escargot de Barjac," for having provided 428 live snails.

\section{Supporting Information Available}

431 This information is available free of charge via the Internet at http://pubs.acs.org. 


\section{REFERENCES}

434 (1) European

Commission.

435 http://ec.europa.eu/environment/chemicals/nanotech/faq/definition_en.htm.

436 (2) Guisbiers, G. Size-dependent materials properties toward a universal equation. Nanoscale

437 Res Lett, 2010, 5 (7), 1132-1136. doi: 10.1007/s11671-010-9614-1

438 (3) Banfield, J. F.; Navrotsky, A. Nanoparticles and the Environment; Mineralogical Society of 439 America: Washington, DC, 2001.

440 (4) Kessler, R. Engineered nanoparticles in consumer products: understanding a new 441 ingredient. Environ Health Perspect. 2011, 119(3), A120-A125.

442 (5) SCENHIR. Opinion on: the appropriateness of the risk assessment methodology in 443 accordance with the technical guidance documents for the new and existing substances for 444 assessing the risk of nanomaterials. Brussels.

445 (6) Mitrano, D. M.; Motellier, S.; Clavaguera, S.; Nowack, B. Environ Int. 2015, 77, 132-147.

446 (7) Mueller, N. C.; Nowack, B. Exposure modeling of engineered nanoparticles in the 447 environment. Environ Sci Technol. 2008, 42, 4447-4453.

448 (8) Gupta, S. M.; Tripathi, M. A review of $\mathrm{TiO}_{2}$ nanoparticles. Chin. Sci. Bull. 2011, 56 (16), 4491639.

450 (9) Ropers, M.-H.; Terrisse, H.; Mercier-Bonin, M.; Humbert, B. Titanium Dioxide as Food 451 Additive. In M. Janus (Ed.), Application of Titanium Dioxide. InTech, 2017. Retrieved from 452 http://www.intechopen.com/books/application-of-titanium-dioxide/titanium-dioxide-as-food453 additive

454 (10)Lu, P.-J.; Huang, S.-C.; Chen, Y.-P.; Chiueh, L.-C.; Shih, D. Y.-C. Analysis of titanium 455 dioxide and zinc oxide nanoparticles in cosmetics. Water Air Soil Pollut. 2015, 23 (3), 587-594. 
456 (11)Larue, C.; Baratange, C.; Vantelon, D.; Khodja, H.; Surblé, S.; Elger, A.; Carrière, M. 457 Influence of soil type on $\mathrm{TiO}_{2}$ nanoparticle fate in an agro-ecosystem. Sci. Total Environ. 2018, $458 \quad 630,609-617$.

459 (12)Kiser, M. A.; Westerhoff, P.; Benn, T.; Wang, Y.; Pérez-Rivera J.; Hristovski, K. Titanium 460 nanomaterial removal and release from wastewater treatment plants. Environ Sci Technol. 2009, $461439(17), 6757-6763$.

462 (13) Johnson, A. C.; Bowes, M. J.; Crossley, A.; Jarvie, H. P.; Jurkschat, K.; Jürgens, M. D.; $463 \ldots \mathrm{Xu}, \mathrm{N}$. An assessment of the fate, behaviour and environmental risk associated with sunscreen 464 TiO $\square$ nanoparticles in UK field scenarios. Sci. Total Environ. 2011, 409 (13), 2503-2510.

465 (14) Weir, A.; Westerhoff, P.; Fabricius, L.; von Goetz, N. Titanium dioxide nanoparticles in 466 food and personal care products. Environ Sci Technol 2012, 46 (4), 2242-2250.

467 (15) Sun, T. Y.; Bornhöft, N. A.; Hungerbü hler, K.; Nowack, B. Dynamic probabilistic 468 modeling of environmental emissions of engineered nanomaterials. Environ Sci Technol 2016, $46950,4701-4711$.

470 (16) Maurer-Jones, M. A.; Gunsolus, I. L.; Murphy, C. J.; Haynes, C. L. Toxicity of 471 engineered nanoparticles in the environment. Anal. Chem. 2013, 85, 3036-3049.

472 (17) Nam, D.-H.; Lee, B.; Eom, I.; Kim, P.; Yeo, M.-K. Uptake and bioaccumulation of 473 titanium- and silver-nanoparticles in aquatic ecosystems. Mol Cell Toxicol 2014, 10 (1), 9-17.

474 (18) Gardea-Torresdey, J. L.; Rico, C. M.; White, J. C. Trophic Transfer, Transformation, and 475 Impact of Engineered Nanomaterials in Terrestrial Environments. Environ Sci Technol. 2014, 48 476 (5), 2526-2540.

477 (19) Yeo, M.-K.; Nam, D.-H. Influence of different types of nanomaterials on their 478 bioaccumulation in a paddy microcosm: a comparison of $\mathrm{TiO} 2$ nanoparticles and nanotubes. 
Environ. Pollut. 2013, 178, 166-172.

480 (20) Servin, A. D.; Pagano, L.; Castillo-Michel, H.; De la Torre-Roche, R.; Hawthorne, J.; 481 Hernandez-Viezcas, J. A.; ... White, J. C. Weathering in soil increases nanoparticle CuO 482 bioaccumulation within a terrestrial food chain. Nanotoxicology 2017, 11 (1), 98-111.

483 (21) Bour, A.; Mouchet, F.; Cadarsi, S.; Silvestre, J.; Chauvet, E.; Bonzom, J.-M.; . . Pinelli, 484 E. Impact of $\mathrm{CeO}_{2}$ nanoparticles on the functions of freshwater ecosystems: a microcosm study. 485 Environ Sci Nano 2016, 3 (4), 830-838.

486 (22) Larue, C.; Laurette, J.; Herlin-Boime, N.; Khodja, H.; Fayard, B.; Flank, A.-M.; ... 487 Carriere, M. Accumulation, translocation and impact of TiO2 nanoparticles in wheat (Triticum 488 aestivum spp.): influence of diameter and crystal phase. Sci. Total Environ. 2012, 431, 197-208.

489 (23) Debelle, F. The Medicago truncatula genome. In Biological Nitrogen Fixation; de 490 Bruijn, F. J. John Wiley \& Sons: 2015; pp 787-789.

491 (24) Tesfaye, M.; Samac, D. A.; Vance, C. P. Insights into symbiotic nitrogen fixation in 492 Medicago truncatula. MPMI 2006, 19 (3), 330-341. doi: 10.1094/ MPMI -19-0330.

493 (25) Simonin, M.; Richaume, A.; Guyonnet, J. P.; Dubost, A.; Martins, J. M. F.; Pommier, T. 494 Titanium dioxide nanoparticles strongly impact soil microbial function by affecting archaeal 495 nitrifiers. Scientific Reports 2016, 6(1), 33643. https://doi.org/10.1038/srep33643

496 (26) de Vaufleury, A.; Coeurdassier, M.; Pandard, P.; Scheifler, R.; Lovy, C.; Crini, N.; 497 Badot, P.-M. How terrestrial snails can be used in risk assessment of soils. Environ. Toxicol. 498 Chem. 2006, 25(3), 797-806.

499 (27) Mouchet, F.; Landois, P.; Puech, P.; Pinelli, E.; Flahaut, E.; Gauthier L. CNT 500 ecotoxicity in amphibians: assessment of multi walled carbon nanotubes (MWNT) and 
501 comparison with double walled carbon nanotubes (DWNT). Special focus environmental toxicity 502 of nanoparticles. Nanomedicine 2010, 5(6), 963-974.

503 (28) Lagier, L.; Mouchet, F.; Laplanche, C.; Mottier, A.; Cadarsi, S.; Evariste, L.; Sarrieu, C.;

504 Lonchambon, P.; Pinelli, E.; Flahaut, E.; Gauthier, L. Surface area of carbon-based nanoparticles 505 prevails on dispersion for growth inhibition in amphibians. Carbon 2017, 119, 72-81. 506 https://doi.org/10.1016/j.carbon.2017.04.016

507 (29) Mouchet, F.; Gauthier, L.; Mailhes, C.; Jourdain, M.J.; Ferrier, V.; Triffault, G.; Devaux, 508 A. Biomonitoring of the genotoxic potential of aqueous extracts of soils and bottom ash resulting 509 from municipal solid waste incineration, using the comet and micronucleus tests on amphibian 510 (Xenopus laevis) larvae and bacterial assays (Mutatox ${ }^{\circledR}$ and Ames tests). Sci. Total Env. 2006, 511355 (1-3): 232-246.

512 (30) Nieuwkoop, P.D.; Faber, J. Normal tables of Xenopus laeivs (Daudin). Amsterdam 7 513 North Holland Publ.; 2006.

514 (31) ISO 21427-1. Qualité de l'eau-Évaluation de la génotoxicité par le mesurage de 515 l'induction de micronoyaux-Partie 1: Évaluation de la génotoxicité à l'aide de larves 516 d'amphibiens Water quality—Evaluation of genotoxicity by measurement of the induction of 517 micronuclei—Part 1: Evaluation of genotoxicity using amphibian larvae. 2006.

518 (32) R Core Team. R: a language and environment for statistical computing. R foundation for 519 Statistical Computing; 2015.

520 (33) Fox, J.; Weisberg, S. An $\{\mathrm{R}\}$ Companion to Applied Regression, 2nd ed.; Thousand 521 Oaks CA: Sage, 2011.

522 (34) Graves, S.; Piepho, H.-P.; Selzer, L. Visualizations of Paired Comparisons; 2015.

523 (35) Giraudoux, P. pgirmess: Data Analysis in Ecology; 2017. 
524 (36) Lenth, R. V. Least-Squares Means: The R Package lsmeans. J. Stat. Softw. 2016, 69 (1), $5251-33$.

526 (37) Rafique, R.; Arshad, M.; Khokhar, M. F.; Qazi, I. A., Hamza, A.; Virk, N. Growth 527 Response of Wheat to Titania Nanoparticles Application. NUST Journal of Engineering Sciences $528 \quad 2015,7(1), 42-46$.

529 (38) Prajapati, K; Modi, H.A. The importance of potassium in plant growth-a review. An 530 Online International Journal 2012, 1 (2-3), 177-186.

531 (39) Maathuis, F. J. M. Sodium in plants: perception, signalling, and regulation of sodium 532 fluxes. Journal of Experimental Botany 2014, 65 (3), 849-858.

533 (40) Pi, Z.; Stevanato, P.; Yv, L. H.; Geng, G.; Guo, X. L.; Yang, Y., ... Kong, X. S. Effects 534 of potassium deficiency and replacement of potassium by sodium on sugar beet plants. Russ. 535 J. Plant Physiol. 2014, 61 (2), 224-230.

536 (41) Servin, A.; Morales, M. I.; Castillo-Michel, H.; Hernandez-Viezcas, J.; Munoz, B.; Zhao, 537 L.; Nunez, J. E.; Peralta-Videa, J. R.; Gardea-Torresday, J. L. Synchroton verification of TiO 2 538 accumulation in cucumber fruit : a possible pathway of $\mathrm{TiO}_{2}$ nanoparticle transfer from soil into 539 the food chain. Environ Sci Technol. 2013, 47 (20), 11592-11598.

540 (42) Rafique, R.; Zahra, Z.; Virk, N.; Shahid, M.; Pinelli, E.; Kallerhoff, J.; Park, T. N.; 541 Arshad, M. Data on rhizosphere $\mathrm{pH}$, phosphorus uptake and wheat growth responses upon $\mathrm{TiO}_{2}$ 542 nanoparticles application. Data in Brief. 2018, 17, 890-896.

543 (43) Imran, M.; Gurmani, Z. A. Role of macro and micro nutrients in the plant growth and 544 development. Science Technology and Development (Pakistan), 2011. Retrieved from 545 http://agris.fao.org/agris-search/search.do? recordID=PK2012000898

546 (44) Ge, Y.; Priester, J. H.; Van De Werfhorst, L. C.; Schimel, J. P.; Holden, P. A. Potential 
547 mechanisms and environmental controls of $\mathrm{TiO} 2$ nanoparticle effects on soil bacterial 548 communities. Environmental Science and Technology. 2013, 47, 14411-14417.

549 (45) Ge, Y.; Schimel, J. P.; Holden, P. A. Identification of soil bacteria susceptible to $\mathrm{TiO}_{2}$ 550 and ZnO. Appl. Environ. Microbiol. 2012. 78, 6749-6758. doi:10.1128/AEM.00941-12

551 (46) Simonin, M.; Martins, J. M. F.; Le Roux, X.; Uzu, G., Calas, A.; Richaume, A. Toxicity 552 of $\mathrm{TiO} 2$ nanoparticles on soil nitrification at environmentally relevant concentrations: lack of 553 classical dose-response relationships. Nanotoxicology 2017, 11 (2), 247-255.

554 (47) Bissett, A.; Brown, M. V.; Siciliano, S. D.; Thrall, P. H. Microbial community responses 555 to anthropogenically induced environmental change: towards a systems approach. Ecol. Lett. 556 2013, 16 Suppl 1, 128-139.

557 (48) van der Heijden, M. G. A.; Bardgett, R. D.; van Straalen, N. M. The unseen majority: soil 558 microbes as drivers of plant diversity and productivity in terrestrial ecosystems. Ecol. Lett. 2008, $559 \quad 11(3), 296-310$.

560 (49) Scheifler, R.; de Vaufleury, A.; Coeurdassier, M.; Crini, N.; Badot, P.-M. Transfer of Cd, $561 \mathrm{Cu}, \mathrm{Ni}, \mathrm{Pb}$, and $\mathrm{Zn}$ in a soil-plant-invertebrate food chain: a microcosm study. Environ. Toxicol. 562 Chem. 2006, 25 (3), 815-822.

563 (50) Eybe, T.; Audinot, J.-N.; Udelhoven, T.; Lentzen, E.; El Adib, B.; Ziebel, J., ... Bohn, T. 564 Determination of oral uptake and biodistribution of platinum and chromium by the garden snail 565 (Helix aspersa) employing nano-secondary ion mass-spectrometry. Chemosphere. 2013, 90 (6), 566 1829-1838.

567 (51) Gogos, A.; Moll, J.; Klingenfuss, F.; van der Heijden, M.; Irin, F.; Green, M. J.; Zenobi, 568 R.; Bucheli, T. D. Vertical transport and plant uptake of nanoparticles in a soil mesocosm 569 experiment. J Nanobiotechnology 2016, 14 (40). doi: https://doi.org/10.1186/s12951-016-0191-z 
570 (52) Chenon, P.; Gauthier, L.; Loubières, P.; Séverac, A.; Delpoux, M. Evaluation of the 571 genotoxic and teratogenic potential of a municipal sludge and sludge-amended soil using the 572 amphibian Xenopus laevis and the tobacco: Nicotiana tabacum L. var. xanthi Dulieu. 573 Sci. Total Environ. 2003, 301, 139-150.

574 (53) Mouchet, F.; Cren, S.; Cunienq, C.; Deydier, E.; Guilet, R.; Gauthier, L. Assessment of 575 lead ecotoxicity in water using the amphibian larvae (Xenopus laevis) and preliminary study of 576 its immobilization in meat and bone meal combustion residues. Biometals. 2007, 20(2), 113-127.

577 (54) Bekaert, C.; Rast, C.; Ferrier, V.; Bispo, A.; Jourdain, M. J.; Vasseur, P. Toxicity and 578 genotoxicity of industrial soils polluted by polycyclic aromatic hydrocarbons (PAHs). Org. 579 Geochem. 1999, 30, 953-962.

580 (55) Bacchetta, R.; Tremolada, P.; Di Benedetto, C.; Santo, N.; Fascio, U.; Chirico, G., . . . 581 Mantecca, P. Does carbon nanopowder threaten amphibian development? Carbon N Y, 2012, 50 $582 \quad(12), 4607-4618$.

583 (56) Bacchetta, R.; Santo, N.; Fascio, U.; Moschini, E.; Freddi, S.; Chirico, G.; Camatini, 584 M.; Mantecca, P. Nano-sized $\mathrm{CuO}, \mathrm{TiO} \square$ and $\mathrm{ZnO}$ affect Xenopus laevis development. $585 \quad$ Nanotoxicology. 2012, 6, 381-398.

586 (57) Zhu, X.; Zhu, L.; Duan, Z.; Qi, R.; Li, Y.; Lang, Y. Comparative toxicity of several metal 587 oxide nanoparticle aqueous suspensions to Zebrafish (Danio rerio) early developmental stage. $J$ 588 Environ Sci Health A Tox Hazard Subst Environ Eng 2008, 43 (3), 278-284.

589 (58) Federici, G.; Shaw, B. J.; Handy, R. D. Toxicity of titanium dioxide nanoparticles to 590 rainbow trout (Oncorhynchus mykiss): gill injury, oxidative stress, and other physiological 591 effects. Aquat. Toxicol. 2007, 84(4), 415-430. 